\title{
Putting theory to work: the use of theory in construction research
}

Article

Accepted Version

Schweber, L. (2015) Putting theory to work: the use of theory in construction research. Construction Management and Economics, 33 (10). pp. 840-860. ISSN 1466-433X doi: https://doi.org/10.1080/01446193.2015.1133918 Available at https://centaur.reading.ac.uk/54469/

It is advisable to refer to the publisher's version if you intend to cite from the work. See Guidance on citing.

To link to this article DOI: http://dx.doi.org/10.1080/01446193.2015.1133918

Publisher: Taylor \& Francis

All outputs in CentAUR are protected by Intellectual Property Rights law, including copyright law. Copyright and IPR is retained by the creators or other copyright holders. Terms and conditions for use of this material are defined in the End User Agreement.

\section{www.reading.ac.uk/centaur}

\section{CentAUR}

Central Archive at the University of Reading

Reading's research outputs online 


\section{Putting theory to work: The use of theory in construction research}

\section{ABSTRACT}

Attention to epistemology, theory use and citation practices are all issues which distinguish academic disciplines from other ways of knowing. The paper uses examples from construction research to outline and reflect on these issues. In doing so, the discussion provides an introduction to some key issues in social research as well as a reflection on the current state of construction research as a field. More specifically, the paper discusses differences between positivist and interpretivist epistemologies, the role of theory in each and their use by construction researchers. Philosophical differences are illustrated by appeal to two published construction research articles on innovation (Reichstein, Salter and Gann 2005, Harty 2008). An analysis of citations for each highlights different cumulativity strategies. The paper concludes with a discussion of the potential contribution of mixed research programmes, combining positivist and interpretivist research. The paper should be of interest to early researchers and to scholars concerned with the ongoing development of construction research as an academic field.

\section{Key Words}

Positivism, Interpretivism, Social Theory, Problem-based research, Construction research, Cumulativity 


\section{Putting theory to work: The use of theory in construction research}

Construction researchers face a herculean task, trying to develop work which addresses the concerns of industry, policy makers and academics. In the process, the specificity of each sometimes gets overlooked. This paper focuses exclusively on construction research as an academic endeavour. More specifically, it explores the use of social theory. While industry and policy contributions are not considered, the underlying assumption is that one of the crucial roles of social theory in construction research is to help break with taken-for-granted assumptions, thus creating the possibility for new policy and industry relevant insights into construction and contributing to the consolidation of construction research as a distinct field and to greater engagement with other social sciences. The discussion will hopefully be of interest to early researchers beginning their engagement with social theory and more established researchers concerned for the ongoing development of construction research as an academic field.

Academic fields can be divided into two types: those which are domain focused and those which are discipline focused. ${ }^{1}$ The former are constituted around a common substantive area, delimited by geography or type of activity. Examples include area studies, such as Russian Studies or Chinese Studies, or professional domains, such as Education or Construction Research. They are consolidated around contributions to empirical problems; they tend to be eclectic about theories and approaches, treating

\footnotetext{
${ }^{1}$ My thanks to Roine Leiringer for this point. For a more sociological discussion of variations in types of disciplines see (Becher and Trowler 2001) and the many discussions which that work launched.
} 
them as tools to be mobilized rather than as perspectives to be explored. The latter are closer to Thomas Kuhn's famous model of disciplines as paradigms (Kuhn 1996). They develop around a shared set of problems, methods, criteria for what counts as knowledge and exemplars (sample pieces of research which both set a research agenda and provide a model for how to work). This knowledge is consolidated in textbooks and internalized into specialized professional identities. Academic disciplines such as Physics, Chemistry and Geography fit this latter model, although each contains multiple, relatively coherent sub-disciplines and boundaries are continually being reconfigured (often through hybridization).

For the purposes of this paper, the distinction supports two points concerning domain-based fields such as Construction Research. First, while domains benefit from a multiplicity of approaches and the intellectual discipline imposed by a relatively well bounded research object, they tend to lack coherence. Secondly, this lacuna can be countered by reflexivity, where reflexivity refers to explicit reflection on theoretical approaches deployed and their consequences for specific findings and to direct engagement with the substantive details of colleagues' findings and arguments. This paper explores both aspects from a variety of different perspectives; the aim is to contribute to an ongoing conversation on the state of the field and more reflexive engagement.

The term 'theory' is used in widely different ways. This discussion begins from a very general definition; for the purposes of this paper 'theory' refers to the elaboration of an abstract framework of concepts which involve the specification of entities and 
types of relations and interactions (which can be idealized in models) and are used by researchers in a given discipline or field to pose questions about some aspect of either the physical or social world. 'Social theory' refers to theories which include actors in their accounts. This very general definition obscures important differences and debates over the nature of theoretical claims (syntactic - involving a set of logically related first order propositions versus semantic - constituted by models), the place of models (constitutive of theories, external to them or even as proto-theories) and the nature of explanation, amongst other topics. ${ }^{2}$ Regardless of which stance philosophers and practitioners adopt, there is a shared sense that the mobilization of theories (or at least models) is one of the key things which distinguishes scientific and/or academic knowledge from other ways of knowing about the world. This discussion focuses explicitly on social theory. More specifically, it contrasts positivist and interpretivist approaches to social research.

The place of discussions of positivism and interpretivism at the beginning of most social research textbooks attests to their perceived relevance. Despite this, construction students and researchers without social science backgrounds often confuse the two, applying criteria from one to evaluate work produced with the other or attempting to address questions which belong to one, with the other. While this is understandable, it gets in the way of communication within the construction research

\footnotetext{
${ }^{2}$ It is interesting to note, that the Stanford Encyclopedia of Philosophy does not contain an entry on 'theory'. Instead, the issues of: what is a theory and what role does it play in the production of scientific knowledge figure under the heading of 'Models in Science'. For an overview of these issues see: Frigg, Roman and Hartmann, Stephan, "Models in Science", The Stanford Encyclopedia of Philosophy (Fall 2012 Edition), Edward N. Zalta (ed.), URL = <http://plato.stanford.edu/archives/fall2012/entries/modelsscience/>.
} 
community, of developing cumulative bodies of social construction research knowledge and of diffusing our work beyond the confines of construction research to the broader academic world.

As distinctive epistemologies (ways of knowing things about the world), positivism and interpretivism differ in the type of questions they ask, in the methods they deploy and in their criteria of evaluation. In the interest of simplicity, two wellcited articles on innovation in construction will be used to illustrate the discussion, although many more could have been selected. I have chosen innovation because it is a vibrant, relatively coherent area of research which includes work from a wide variety of methodological and theoretical perspectives. The two articles are: Reichstein, Salter and Gann's (2005) study of attitudes towards innovation in the construction sector and Harty's (2008) paper on technological innovation.

Reichstein et al's study is driven by a concern to explain the supposedly low level of innovation in construction. To address this issue the authors conducted a quantitative sector level analysis of levels of innovation across manufacturing, service and construction sectors. In contrast, Harty explores the introduction of a new building service modelling tool into a large, complex construction project. Harty is particularly interested in the contrast between the envisioned and actual use and function of Information and Communication Technology (ICT).

\section{A little philosophy}

The distinction between positivism and interpretivism can be traced back to a philosophical debate over whether there is one science or many. At stake are a number 
of fundamental issues, including the aims of science, the use of theory and the nature of explanation. Proponents of the unified view argued that social phenomenon can and should be studied in the same way as natural phenomenon, while proponents of the many sciences view argued that social phenomenon are different and require a different type of science (or no science at all). ${ }^{3}$ The term positivism was initially associated with the unified view; while interpretivism was associated with the many sciences view.

\section{The Unified position: positivism(s)}

The positivist philosophy

The term 'positivism' is generally ascribed to $19^{\text {th }}$ century philosopher Auguste Comte (1798-1859) who used it to refer to the highest or most developed form of knowledge. While his approach is no longer at the centre of philosophical attention, it continues to exert a strong influence on empirical research, including on construction research.

Comte's philosophy of science was introduced in a series of works, published between 1830 and 1842 under the title of Cours de Philosophie Positive; these four volumes established the use of the term positivism to describe science and more specifically social science. Comte worked with a model of knowledge as divided into different topics or disciplines, including chemistry, biology, physics and sociology. ${ }^{4} \mathrm{He}$ argued that each of them develops through the same set of historical stages from the theological, to the metaphysical to the positivist or scientific. The primary characteristic

\footnotetext{
${ }^{3}$ For a clear, highly respected review of this debate see: (Hollis 1994)

${ }^{4}$ For a historical account of the emergence of positivism and the role of Comte's work in the division of scientific knowledge into discrete disciplines see (Heilbron 1995).
} 
of positivist knowledge (the final and highest stage) is the search for general or universal laws, grounded in observation.

'Laws' in Comte's sense refer to regularities in the relations between variables. In this sense, they are descriptions of patterns, rather than the kind of ultimate laws which figure in many natural sciences today. As indicated above, the relevance of Comte's view for this paper is that it captures the aims and approach of much positivist construction research. For example, Reichtein et al's aim is to establish general laws regarding the effect of sector level characteristics on sector levels of innovation.

One of the main criticisms of Comtean positivism is that, just as the fact that the sun rose this morning does not guarantee that it will necessarily rise tomorrow, so too empirical observation alone cannot establish the truth of a law (certainty). ${ }^{5}$ As Keat and Urry explain, the problem is: "how can one justifiably argue from past events to future events, from the known to the unknown" $(1982$, p.15). To deal with this problem of certainty, or rather uncertainty, positivists tend to use statistics to make probabilistic claims. This allows them to quantify initially observed patterns and to identify probabilistic rather than certain laws.

Reichstein et al's paper illustrates a positivist approach to innovation. The aim of the study is to account for reportedly low levels of innovation in the construction sector

\footnotetext{
5 The example of the sun rising - or not rising - tomorrow is taken from David Hume (2011 (1748)) and often used to make this point. The difficulty is an instance of David Hume's "problem of induction." As Hume described it in 1748's An Enquiry Concerning Human Understanding, "all inferences from experience suppose, as their foundation, that the future will resemble the past, and that similar powers will be conjoined with similar sensible qualities. If there be any suspicion that the course of nature may change, and that the past may be no rule for the future, all experience becomes useless, and can give rise to no inference or conclusion" (Section IV, pt. 2, para. 8).
} 
relative to other sectors. To explore the claim, the authors examine national level survey data on professional perceptions of innovation across many sectors. They then link perceived differences in innovation performance to sector specific characteristics. In keeping with a positivist approach, the paper frames the problem in terms of the relation between variables. More specifically it examines the statistical relation between a number of sector characteristics which are deemed to inhibit innovation (which they refer to as 'liabilities') and levels of innovation. Sector level liabilities include: the project based character of construction work, in-situ production (and the associated liability of immobility), uncertainty of demand, the small size of many firms, the separation of design and production and the nature of the supply chain.

\section{Logical Positivism and Falsificationism}

Reichstein et al's paper offers a contemporary illustration of Comte's model of positivist research as the use of observations to identify patterns. However, as indicated above, critics question the move from observation to general laws. In the $20^{\text {th }}$ century, philosophers associated with the Vienna School and its critics offered an alternate view of science. This debate altered the meaning of the term 'positivism' and dominant understandings of the role of theory in science.

The term 'logical positivism' refers to the work of a group of German and Austrian philosophers who developed a version of the unified view in the 1930s (and subsequently in Britain and the US). Karl Popper was part of this conversation, but broke with the logical positivists over the nature of scientific claims. He described his alternate approach as 'critical rationalism' or 'falsificationism'. 
Logical positivism began from the premise that the specificity of science lay in a particular type of explanation, whereby general principles or laws were used to explain empirical phenomenon. This approach placed deduction and logic at the heart of the scientific endeavour. The place of experiments in logical positivism is to verify theoretically derived claims. This approach supports a view of scientific knowledge as certain and True (with a capital T). Popper, in contrast, had a more modest view of science. Instead of establishing the truth of a proposition, experiments leave open the possibility that theories or claims are not false. Thus, while it is not possible to confirm hypotheses (after all, the sun might not rise tomorrow!), it is possible to falsify them (Popper 1962/2002). The essence of science, according to this view, is the testing and potential falsification of theoretically derived hypotheses.

For the purposes of this discussion, an important component of both logical positivism and falsificationism lies in the central importance which they ascribe to theory. Theory is both the source of new ideas and the basis for the cumulativity of scientific knowledge. In contrast to the Comtean view that observations or induction are the source of new ideas and explanations (general laws), logical positivists and Popper placed theory, and more specifically theory testing, at the heart of the scientific endeavour. They argued that science begins from conjectures or theories which use logic to suggest possible patterns or relationships between variables. These laws are then either verified (logical positivists) or tested (Popper 1962/2002) against independent observations. Thus, whereas for Comte the cumulativity of scientific 
knowledge lay in the accretion of empirically certified truths, for Popper it lay in the development and successive substitution of theories(Niiniluoto 2015).

To summarize the unified view of science set the aim of science as the identification of (general or universal) covering laws. In this 'positivist' approach, the aim of scientific research is to 'explain' particular cases or phenomenon by relating them to general covering laws. Thus, one can say that $y$ is caused by $x$, because $y$ and $x$ are specific instances of a causal law (Neumann 2006: , p.84). Explanatory theories involve probabilistic statements about the correlation between variables. Where Comte and Popper differ is in the certainty of the claims which scientists can make and in the role of theory. For the latter, theory development and empirical testing of theoretical claims is what distinguishes science from other ways of knowing.

Positivism, independence and objectivity

Before moving on, a number of features of this approach are worth noting as they relate to common misconceptions concerning the nature of positivist social research. The first concerns the independence of the data from the theory and the second involves the 'objectivity' of the researcher.

Positivism has come under a number of criticisms, especially since the 1970's. A key issue concerns the presumed independence of observation and the objectivity of the observer. Both Comte and Popper's models for science assume that observations and thus empirical data exist independently of the observer, their theories and their hypotheses (for it is only if they are independent that they can be used to confirm or falsify particular laws). In a very influential critique, Peter Winch (1958) argued that 
observations are always shaped by concepts in the minds of the observer. As such, they are never independent of theory or received understandings. For example, in Reichstein et al's study, observations are taken from the UK segment of the Eurostat Community Innovation Survey (CIS) of innovation. The survey has been administered since the early 1990s and the questions (which produce the observations) have been evaluated and reworked extensively since then. Thus, while they are 'independent' of Reichstein et al's own analytic framework, they are not based on 'pure' observation. Instead the data has been shaped by other scholars' theories of innovation and research (much of which Reichstein et al can be presumed to have read) and by respondents' 'subjective' views.

Far from discrediting this type of research, the theory laden, subjective character of observations is inevitable. Winch and other critics point is not that we should not do quantitative or positivist social research, but is rather that scholars should acknowledge their personal and theoretical biases and take that effect into account when they draw conclusions. Thus, whereas Popper believed in the power of independent observation to falsify 'subjectively' held theories, critics emphasise the importance of reflexivity and the associated awareness of biases necessarily built into any perspective or theory.

\section{The many sciences view: Interpretivism}

In the 1970's, the criticisms outlined above led to a revival of $19^{\text {th }}$ debates over social science and method and an interest in the many sciences (non-unified) stance.

The many sciences position begins from the premise that social phenomena are qualitatively (sic) different from natural phenomena and as such should not be studied in the same way. Instead of one science, proponents of this view argue for many. In 
discussing this position, it is important to note that while the many sciences philosophers reject the idea of a singled unified science, they do not necessarily reject the possibility of a science of society. Historically, proponents of this view argued for a different kind of (social) science; today interpretivists are divided as to whether they see their research as 'science' or 'not-science'.

\section{The Methodenstreit}

The many sciences view is usually ascribed to the Methodenstreit debate in economics. This was a debate between the Austrian School (with a unified science view) and the German Historical School (with a many sciences view) which began in the 1880s and continued well into the $20^{\text {th }}$ century. At the time, economics was the only distinct social science; as such the debate is really more about social science than economics in today's narrower sense. The many sciences view built on the work of Wilhelm Dilthey (1833-1911) and Max Weber (1864-1920). Both scholars began from the observation that human behaviour is shaped by meaning in the form of understandings, intentions and motivations. Moreover, it is mediated by language and symbols. This means that to 'explain' social phenomena, scholars need to study the meanings which people ascribe to acts and objects. To study meaning, scholars need to interpret their data (Weber 2011 (1903-1917)). Thus, whereas positivists assume that facts can be read directly off of observations, interpretivists argue that the social science depends on the interpretation of data.

Whereas positivism is a relatively coherent epistemology, interpretivism covers a variety of quite different approaches, including: constructivism, phenomenology, 
ethnomethodology, pragmatism and post-modernism, to name but a few. Very generally, it is helpful to distinguish between interpretivist approaches which focus on meaning, those which privilege process and those which are interested in documenting heterogeneity or variation. Interpretivist research differs from positivist research in the type of explanation, and thus knowledge, which it aspires to produce. For positivists, explanation involves the association of a particular case with an already established general law. For interpretivists focused on meaning, explanation involves reconstructing the meanings and understandings which led people (or firms or teams) to act in a particular way. For interpretivists concerned with process, the aim of academic research is to document sequences of events which produce particular outcomes (as well as meaning). Finally, for those interested in variation, the focus is on the effects of context on seemingly similar processes or events. Thus, whereas positivism generally focuses on similarities across cases, leading to the formulation of general laws, interpretivist research is often more interested in differences.

The Harty article cited above offers an example of one type of interpretivist approach to innovation. In his study of a new building service modeling tool, Harty focuses on innovation as a process which encompasses what is usually described as implementation or diffusion. Instead of looking for the variables which explain the success or failure of the tool in a specific project, Harty asked: Who was involved in implementing the tool? What were their expectations and interests? What meaning did each of them ascribe to this new tool? and How did they use it? The primary aim of the research is not to predict the use of the tool, but rather to document how it came to be 
used in a particular way. The analysis focuses on the network of actors and artefacts which are mobilized around the use of new ICT.

As this brief description suggests, a number of assumptions inform this study. First, Harty begins from the assumption that the use of ICT is not determined by the technology but instead varies; secondly, his analysis assumes that the experience and meaning of innovation varies across subjects; and thirdly, the study treats innovation as a dynamic process rather than as a fixed entity. The main point that I wish to make here is that explanation in interpretivist research depends not only on getting into the heads of the subjects (and the cultural resources which informed their interpretations), but also in documenting the sequence of events and contexts which produced a particular outcome.

Interpretivism and generalisation

One of the common criticisms of interpretivism is that knowledge is limited to specific cases. While many studies do indeed focus on documenting variations or identifying novel or surprising outcomes; others use those cases to nuance and develop theories (which, in turn, raise new questions and foster further research).

Generalisation, for interpretivists, thus lies in theory development, where the term 'theory' refers, not to the development of general laws, but rather to the identification of mechanisms and processes, whose effect varies across different contexts.

This focus on theory development can be illustrated by Harty's article. A key contribution of the article lies in the introduction of a new concept - namely the relative boundedness of innovation - and the types of processes which this abstract 
(theoretical) process involves. For Harty, the concept of boundedness refers to the effect of a local context on an innovation and its use. A bounded innovation is one which is relatively untouched by the context; an unbounded one is an innovation whose effect extends well beyond what is originally intended. In the case of new ICT, the technology developers had a clear vision of how the technology would be used. However, construction professionals in the case study did not adopt this model. Instead they combined 3D and 2D images, they re-invented ICT and used it to suit their purposes and they were guided by other standards. In his paper, Harty uses this analysis to identify general processes which contribute to the unboundedness of an innovation. In other words, he used the empirical case study to contribute to theory development.

As this account suggests, interpretivism is often 'more inductive' than positivism, in the sense that the movement is from empirical cases to theory development. However, just as positivism combines both theory and empirical data in practice, so too interpretivist research involves an iterative process whereby theory is used to specify initial constructs, which are used to begin exploring an empirical case, which in turn provides the basis for theoretical revision and redefinition. In Harty's case, he began with Actor Network Theory which provided him with a very specific ontology and method. The ontology or analytic framework focused his attention on the network of actors and artefacts engaged in the introduction and development of a new technology, while the method drew his attention on the scope of the network and thereby to the concept of unbounded innovation. 
Interpretivism, theory and subjectivity

Whereas positivism is often misrepresented as being more 'objective' than it actually is, interpretivism is often dismissed as subjectivist in the sense of 'merely opinion.' This judgement conflates the meanings which subjects' mobilise in their everyday activities with the researcher's interpretation of those meanings and activities. It also ignores the core precepts of interpretivist research, namely the call for reflexivity. Thus, whereas the everyday knowledge of the research subjects is generally a combination of common sense, tacit knowledge, reasoned views and unexamined assumptions; the knowledge which the researcher produces should (at its best), be the product of systematic, epistemologically controlled analysis, in which key assumptions are examined and justified and their impact on the findings is scrutinized and explained.

The role of theory in interpretivist research lies largely in helping researchers to rein in or move beyond their own subjective opinions and common sense views of their research object. Done well, the dialogue between theory and empirical data combined with a meta-analysis of the way in which theory shapes data should produce knowledge which is interpretivist, but far more rigorous than 'just opinion.' Stated differently, the role of theory is to displace the researchers own common sense and to allow them to see things differently than either their subjects or they would have without it. Similarly, the role of data (while partly informed by theory) is to push back against the researcher's own common sense, limiting what can and cannot be claimed. In both cases, this depends on the researcher's awareness of their own assumptions and the way in which they shape the analysis (reflexivity). 
One of the main criticisms of much interpretivist research - and a key challenge for construction research - lies in the neglect of theory. All too often interpretivist studies stop at the rich description of a single case or couple of cases, with no reflection on the implications of that analysis for more abstract analytical frameworks or general understandings. As Harty's article illustrates, the function of theory is to link rich empirical description to more general processes and concepts which can be mobilized in future studies on similar and very different empirical cases.

\section{Summary: positivism vs interpretivism}

This discussion began from a concern to explain the contribution of theory to construction research and to help clarify the well established distinction between positivist and interpretivist approaches. The discussion underlines the centrality of theory to both positivist and interpetivist research. In the case of positivism, theory is the source of hypotheses and propositions which can be tested using empirical data. In interpretivist research, theory is a tool to displace the researchers' own common sense and to draw attention to processes and meanings which, while hidden from view, are essential to understand observed outcomes. In both cases, the aim of research is (not only empirical description but also) theory development.

Turning to the contrast between them, positivist and interpretivist social research differ in the type of research questions, methods and criteria for evaluation. Whereas positivism asks about patterns in the relation between variables and uses quantitative or formal descriptive methods to establish probabilistic relations between them; interpretivism asks about the multiple interpretations which subjects bring to the 
same event and the impact of those different meanings on their behaviour as well as the processes which produced a particular outcome or event. And whereas positivism seeks explanation in the relation between general laws and particular incidents; interpretivism looks for it in the temporal and interpretive processes which produce observable outcomes. Following on from this, positivists evaluate research in terms of different properties of its theories and experiments. These include criteria such as validity (internal and external) and reliability (internal and external). In contrast, interpretivist research is usually evaluated in terms of the plausibility and coherence of the account, although some scholars do provide alternate definitions of terms such as validity and reliability(Hammersley 1992, Guba and Lincoln 1994).

\section{LOOKING FORWARD}

The second half of this discussion reflects on the contribution of theory to the ongoing development and consolidation of construction research as an academic field. This topic raises issues of cumulativity and research design. Like many domain-led fields, construction research is weak on theory development, but this does not mean that theory is or should be irrelevant to construction research. The discussion which follows uses a brief analysis of the ways in which the Harty and Reichstein articles have been cited. The discussion highlights differences in the development of positivist and interpretivist elaborations of colleagues' work. It concludes with a plea for more multiapproach research agendas, combining the strengths of both positivist and interpretivist research in the interest of further problem development. 


\section{Cumulativity in social research}

For philosophers of science, theory development is at the heart of what makes science or academic knowledge distinct. While many scholars believe that generalization, and by extension cumulativity, is linked to theory development, others challenge that view. Davis and Marquis' (2005) distinction between paradigm-driven research and problem-driven research captures this alternate position.

In a review of organization theory, Davis and Marquis (2005) contrast paradigmdriven research and problem-driven research. ${ }^{6}$ While they don't define it, paradigmdriven research would seem to draw on Kuhn's use of the term. As indicated above, paradgims for Kuhn are characterized by a clear theory, with associated research questions and exemplar studies which serve to guide a community of researchers in the production of 'normal'science' (Kuhn 1996). Cumulativity in this model occurs within the paradigm and depends on it. Examples in the study of organizations include: transaction cost economics, resource dependence theory, organizational ecology, new institutional theory, and agency theory in financial economics (Davis and Marquis 2005). Problem-driven research, in contrast, is informed by the attempt to understand major social and economic transitions and to solve big substantive problems, such as: "How have Japanese firms' labor practices changed in response to the extended economic downturn? What is the organizational texture of China's transition to capitalism? How do market pressures change the way health care is delivered? How do corporate elites

\footnotetext{
${ }^{6}$ For a further elaboration of this argument as regards Organization Theory see the more recent paper by Davis (2015) and the rebuttal by Lounsbury and Beckman (2015).
} 
maintain their power in the face of challenges arising out of "shareholder

capitalism?"(Davis and Marquis 2005, p. 334) For the purposes of this discussion, questions about the diffusion and uptake of innovation across the construction sector would count as topic worthy of problem-driven research. In defining problem-driven research, the authors are careful to distinguish it from consultancy and other forms of industry defined research which attend to the short term demands of firms and as a result do not contribute to cumulativity of either kind.

For Davis and Marquis, the distinction between paradigm-driven and problemdriven research maps loosely onto the positivist/interpretivist distinction with paradigmdriven research involved in testing theoretically informed hypotheses and problemdriven research concerned with the search for mechanisms. In the discussion which follows, l'd like to suggest that the relation between the two is less tight than Davis and Marquis suggest. More specifically, construction research, like most domain-based disciplines, is a problem-driven field which draws on both (a more descriptive version of) positivist research and on interpretivist research.

Citation practices in construction research

Keeping this brief set of reflections in mind, it is instructive to review citations to the Harty and Reichstein et al papers. As indicated in the opening to this discussion, the topic of innovation was chosen as a growth area for construction research. The two papers were selected as high quality, relatively well-known examples of positivist and interpretivist contributions. As such, one would expect citations to the papers to contribute to the development of knowledge about construction innovation. 
The usual way to trace citations is the Science or Social Science Citation Index. However, this index does not pick up on a number of key construction journals, including Construction Management and Economics. The search engine, Business Source Complete (BSC) offers an alternate route. The database was examined in a previous paper and deemed to include the key journals in the construction field (Schweber and Leiringer 2012). According to BSC, the Reichstein paper was cited by 27 other papers in its data base, while the Harty paper was cited by 28 other publications. On examination, one of the Reichstein papers proved not to cite the paper and was thus eliminated. In the case of the Harty paper, one of the identified articles was a book review, another was the introduction to a special issue and a third was in Spanish. All three were removed. Articles by one of more of the original authors were retained. This left 26 articles which cited Reichstein and 25 which cited Harty. Since some articles cited the authors more than once, this produced 41 citations to Reichstein's paper. It provided 38 references to Harty's paper, one of which was a reference by the author to a more complete account of his own research. This was dropped, making a total of 37 citations. The papers are listed in Appendix 1 and will be referred to by letter and number (e.g. R7, H2). A search for discussions of referencing typologies did not provide any useful resources, so a set of categories was developed based on the problem at hand. The 78 references were classified as 1. Approach, 2. Academic Common Sense, 3. General Contribution, 4. Author's Specific Contribution and 5. Theory development. The first category refers to citations which highlight the approach used. In Reichstein's paper, this included topics such as the use of quantitative analysis (R18), 
the challenge of classifying the construction sector (R1, R9, R11 and R13) or the six liabilities (R5, R15 and R16). It is worth noting that of these three references, only one indicated that Reichstein et al had borrowed this classification from Nam and Tatum. In Harty's paper, citations varied from the use of ANT in organization studies $(\mathrm{H} 5, \mathrm{H} 23)$ or in construction research $(H 7, H 9)$, to the study of objects as actors $(H 17, H 18, . H 23$ and $\mathrm{H} 25)$.

The second category, Academic common sense, refers to general points which are not specific to that article and for which a number of other articles could just as easily have been cited. Examples include the use of Reichstein and Harty to support claims concerning the low levels of innovation in general (R21, R25 and H24) or relative to manufacturing $(R 6, R 17)$ and low levels of technical development (R12, R15, R16 and H3) in the construction sector. Similarly, a couple of articles, cited Harty for the need to import techniques from other industries into construction to improve innovation performance ( $\mathrm{H} 20$ and $\mathrm{H} 21)$, even though Harty himself does not make this argument but rather refers to it in passing. References varied from blunt claims (some of which misrepresented the authors' own arguments) to slightly more nuanced arguments about 'perceived low levels of innovation' (R8, R9, R19, R23 and H3). In one instance, Harty was cited for a definition of 'radical innovation' (H12) which he had credited to Slaughter (1998) and in another he was cited for research into the governance of construction projects $(\mathrm{H} 1)$, which was somewhat of a stretch. As these examples suggest, references in this category tended to draw on points introduced in the front half of the papers, either in the initial framing of the problem or in the literature review. 
The third category refers to points which are central to the paper, but so general that they do not pick up on the specificity of the authors' findings or argument. The distinction between this category and the fourth one, namely references to the author's own contribution, is difficult to draw, especially as both authors can be seen to have influenced received wisdom in the field. The point here is only that there is a spectrum of claims, ranging from more general findings, which often echo other published work and help to strengthen their claims to those that are more specific. Taken together references to general and specific claims make up a little over $1 / 3$ of all references in each article. The precise breakdown (keeping in mind the continuum passing from the general to specific contribution category) can be found in Table 1.

In Reichstein's case, references to general contributions included points such as contractors limited access to finance for innovation (R3, R4), low levels of investment in $R \& D(R 7, R 20)$ and the importance of inter-organizational ties or the business environment for innovation (R1, R10 and R19). In the case of citations to Harty's paper, they included things like the importance of inter-organizational ties (H10) for innovation, firm level adapation to innovation (H17), innovation as a measure of firm performance $(\mathrm{H} 3)$ and the contribution of trust and communication ( $\mathrm{H} 3)$ - another reference which seems to have stretched Harty's argument considerably.

Other references targeted points which were specific to the author's argument and thus contribution. In the Reichstein et al paper, this included arguments about the importance of the supply chain for innovation in the construction sector (R20, R22), the inhibiting role of specific liabilities, notably immobility and unexpected demand (R2), the 
specific impact of the regulatory context on small firms (R17) and the way in which certain liabilities created a locked system, hostile to innovation (R15). In Harty's case, this category included references to points such as the use of paper alongside CAD design technologies $(H 13, H 18)$ and the concept of bounded innovation $(H 2, H 9, H 13)$

Table 1 summarises the type of citations to each article. None of the citing papers engaged in theory development. While this might seem surprising from a social science textbook perspective, it fits with Davis and Marquis' observations concerning the (academic) problem based character of organization theory and the management literatures. As indicated above, the boundary between the two types of contribution is fluid. Appendix 2 provides a full list of the citations and how they were classified. <insert Table 1 here>

From the perspective of construction innovation research, the second category, Academic Common Sense, and the third category, General Contributions, can be deemed to contribute little to cumulativity. The fourth category, Authors Contribution, includes references to key findings or problem definitions which are specific to the paper. These could potentially contribute to the refinements of existing research problems and understandings and thereby, to the use of the cited article for cumulative problem definition.

Strategies of cumulative problem development in construction research A closer review of papers classified as citing either Reichstein et al or Harty for their authors' specific contributions identified four papers building on Reichstein (R1, 
R15, R17 and R19) and three building on Harty ( $\mathrm{H} 2, \mathrm{H} 9$ and $\mathrm{H} 13)$. A review of these contributions identifies a number of strategies for cumulative problem-driven research.

Amongst papers building on Reichstein et al, Manley and McFallen (R19) elaborated the authors' general argument that the business environment is a crucial determinant of levels of innovation by distinguishing between market conditions and business strategies. This offers an example, of using an existing paper as an exemplar; it involves adopting the cited paper's approach and general argument, but exploring it further by refining the variables using more detailed sector level data. Whereas in this paper Manley and McFallen expand and refine the independent variables, two other papers refine the dependent variable. Both Lim et al (R15) and Bröchner (R1) build on Reichstein et al ,by distinguishing between types of innovation in the construction sector. Finally, a second paper by Manley (R17) used Reichstien et al's finding that small firms are more likely to find regulations to be an obstacle to innovation as the basis for a more in-depth qualitative inquiry (see below). Taken together these examples offer two different types of problem development building on positivist research designs. In the first three of these examples, authors build on Reichstein et al's positivist research design by elaborating particular variables. In the fourth paper, the author uses their positivist study to identify a problem for further exploration using an interpretivist approach.

The interpretivist research design in Harty's paper means that problem development takes a slightly different form. Two papers build on the concepts of (un)bounded innovation. While they do not further theorize the concept, they do use it 
it to characterize and explore dynamics around different aspects of construction activity, thus contributing to problem development. Clegg and Kreiner (H2) use the concept to underline the ambiguity and shifting set of issues and actors engaged in project level innovations. Their research contrasts the meaning of innovations prior to an accident and afterwards and the implications of that discursive shift for the attribution of responsibility and project team learning. In terms of our discussion, their paper shifts the focus from more or less bounded innovations across different projects to changes in the boundedness of a single innovation in a single local context over time. Lingard et al (H9) similarly use the concept of (un)bounded innovation to highlight the broad and shifting range of actors and objects involved in risk management. The point is used to challenge formal approaches to Construction Hazard Prevention through Design (CHPtD) which assuemes a single designer with control over design decisions. In both the Clegg and Kreiner paper and the Lingard et al paper, the concept of unbounded innovation is used to challenge common sense, taken for granted assumptions, thus creating a space for new type of research question. In terms of research design, Harty's concept supports the initial specification of the empirical research problem.

A third paper develops a different aspect of Harty's paper, namely the role that paper continues to play alongside digital technologies in construction work. Neff et al (H13), build on ANT argument about objects as carriers of scripts (which Harty also uses), to explore the ways in which the persistent reliance on paper serves to re-enforce traditional divisions of labour between construction professions and disciplines. This challenges claims for BIM and its impact on construction teams. In all three examples, 
cumulativity involves taking a finding or concept produced by one empirical example and problem and applying it to a different setting and problem.

The point which I want to make with this analysis of citation practices is not that construction researchers should engage in theory development; as Davis suggests, this is not the only way to build on colleagues work. Instead the analysis underlines the need to engage with the specificity of different authors' contributions and to develop appropriate strategies for cumulative research development. It also underlines differences between positivist and interpretivist cumulation strategies.

As the first half of this discussion argues, positivist and interpretivist research designs do different things. As such, their findings should be used differently. Positivist research is oriented towards the identification of patterns across variables which are deemed to hold across cases. The four examples of cumulative citation practices suggest that cumulativity in positivist research comes from further nuancing and exploring specific claims, by differentiating either the independent or dependent variables. In interpretivist research, key findings involve the identification of processes or mechanisms. Cumulativity, as the three examples above all illustrate, depends on identifying a particular mechanism or process and using it to explore a new problem and/or local setting. Of all the papers, Clegg and Kreiner's paper came the closet to theory development, with its shift in the focus of (un)boundedness from variations in the boundedness of innovations to variations within a single innovation. 


\section{Multi-approach research designs}

In closing, I want to return to Manley's proposal to explore one of Reichstein et al's positivist findings with an interpretivist research design. Having just spent a number of pages insisting on the epistemological differences and consequent incompatibility of these two approaches this suggestion may seem strange. But the point here is not to combine the two in a single research design, but rather to develop multi-staged research programmes which use findings produced by one approach to pose questions which can be answered with the other. This type of combination is at the heart of the comparative case study method, which combines interpretivist, holistic case studies with more positivist comparisons across configurations (Lange 2012). But it is not limited to comparative work.

Reichstein et al's article can be used to illustrate this point. The article begins with a six fold classification of obstacles to technological development by Nam and Tatum (1988), based on the latter's reading of the literature and personal reflections on the contrast between manufacturing and construction production. With this in hand, Reichstein et al set out to find statistical data which would allow them to explore this claim in a more systematic fashion. Not having control over the content of the data, their analysis is necessarily limited by the issues and concerns which the designers of the UK Innovation survey (and the Eurostat Community Innovation Survey (CIS) of innovation on which it is modelled) had in mind when they designed their studies. In this case, the authors compare construction statistics with manufacturing, service industries and knowledge intensive industries, on the grounds that construction shares 
features of all three, with a closer proximity to the service sector. To explore the state of the construction sector writ large, they combine data on architecture, engineering consultancy and associated services.

This move is fully justified by their stated aim and methodology, but it also masks significant variations within the construction sector. A next step, as the examples above suggest, would thus be to use interpretivist research to further explore their findings. The aim of the exercise would be to refine the basic propositions, by introducing dimensions which the statistical data could not capture; the analysis could produce a refined set of claims with further scoping conditions and more nuanced propositions.

For example, the main finding in Reichstein et al's paper is that "the liabilities of immobility and unanticipated demand" are among key distinguishing features that separate innovative behaviour in construction from other industries. But are these two liabilities equally spread throughout the construction sector? Or, do they differ by types of construction? If a comparison of housing and commercial construction found that the former was more subject to these liabilities than the latter, this might point to underlying factors, such as the effect of greater standardization in the housing sector an empirical proposition which would invite both further theorization and empirical research. The point here is not to take away from the contribution of this article, but rather to illustrate the way in which positivist research both builds on interpretivist work and provides starting points for future inquiry. 


\section{CLOSING REMARKS}

In closing, let me repeat the main argument, namely that social theory is one of the things that distinguishes academic research and science from other types of research and that part of the "added intellectual value" of social theory lies in its ability to move research beyond common sense understandings to the discovery of new and original ideas. This, as described, can be done through either positivist or interpretivist research design, both of which can be used to contribute to the cumulation of knowledge in domain-based, problem-based research areas such as construction research. That said, the deployment of theory depends on recognising the type of research design being adopted, the type of question, findings and criteria of evaluation which it supports and mobilizing it accordingly, both in the production of research and in the further development of colleagues findings. To this end, the analysis identified two quite distinct ways of building on existing research. The first, associated with positivist approaches, involved further exploring existing findings by nuancing either independent or dependent variables. The second, associated with interpretivist approaches, involves exploring the way in which specific mechanisms or processes identified in one study play out in a second local context around a similar or different research problem.

A review of citation practices around the two articles suggests that the majority of citations pick up on very general points, many of which are not specific to the article being cited, some of which are not even accurate accounts of the author's argument. At a very general level, this points to the need to engage much more carefully in the details 
of our colleagues work (and possibly for more space in journals to develop and present the detailed implications of particular arguments and findings). It also underlines the need to distinguish between different kinds of claims, and more specifically those rooted in positivist versus interpretivist research. Finally, the discussion opens the way for research designs which bridge this epistemological divide, by using interpretivist research design to explore patterns highlighted in positivist research and using positivist research to explore the scope or limits of claims produced in interpretivist research. 
Table 1: Classification of citations to two papers on construction innovation

\begin{tabular}{|l|l|l|l|l|l|}
\hline & Approach & $\begin{array}{l}\text { Academic } \\
\text { Common Sense }\end{array}$ & $\begin{array}{l}\text { General } \\
\text { Contribution }\end{array}$ & $\begin{array}{l}\text { Author's } \\
\text { Contribution }\end{array}$ & $\begin{array}{l}\text { Theory } \\
\text { Development }\end{array}$ \\
\hline $\begin{array}{l}\text { Reichstein et al } \\
(2005)\end{array}$ & 10 & 15 & 10 & 6 & 0 \\
\hline Harty (2008) & 16 & 8 & 4 & 9 & 0 \\
\hline
\end{tabular}




\section{Appendix 1 Citations to Reichstein et al and Harty's papers}

\section{Citations to Reichstein et al (2005)}

R1 Bröchner, J (2010) Construction contractors as service innovators. Building Research \& Information, 38(3), 235-46.

R2 Chiang, Y-H, Bo-Sin, T and Wong, F K W (2008) Volume building as competitive strategy. Construciton Management and Economics, 26(2), 161-76.

R3 Chiang, Y-H and Cheng, E W L (2008) Construction loans and industry development: the case of Hong Kong. Construction Management and Economics, 26(2), 161-76.

R4 Chiang, Y-H and Cheng, E W L (2011) Revealing bank lending decisions for contractors in Hong Kong. International Journal of Project Management, 29(2), 137-45.

R5 Demian, P and Walters, D (2014) The advantages of information management through building information modelling. Construction Management and Economics, 32(12), 1153-65.

R6 Drejer, I and Finding, A L (2006) Organisation, 'anchoring' of knowledge, and innovative activity in construction. Construction Management and Economics, 24(9), 921-31.

R7 Eriksson, P E (2013) Exploration and exploitation in project-based organizations: Development and diffusion of knowledge at different organizational levels in construction companies. International Journal of Project Management, 31(3), 333-41.

R8 Eriksson, P E and Westerberg, M (2011) Effects of cooperative procurement procedures on construction project performance: A conceptual framework. International Journal of Project Management, 29(2), 197-208.

R9 Fitjar, R D and Rodríguez-Pose, A (2015) Interaction and Innovation across Different Sectors: Findings from Norwegian City-Regions. Regional Studies, 49(5), 818-33.

R10 Gajendran, Thayaparan; Brewer, Graham; Gudergan, Siegfried; Sankaran, Shankar. Deconstructing dynamic capabilities: the role of cognitive and organizational routines in the innovation process. Construction Management \& Economics. Mar 2014, Vol. 32 Issue 3, p 246-261.

R11 Gray, C and Davies, R J (2007) Perspectives on experiences of innovation: the development of an assessment methodology appropriate to construction project organizations. 25, 12(1251-1268).

R12 Harty, Chris; Whyte, Jennifer Emerging Hybrid Practices in Construction Design Work: Role of Mixed Media. Journal of Construction Engineering \& Management. Apr 2010, Vol. 136 Issue 4, p 468-476.

R13 Lim, J N and Ofori, G (2007b) Classification of innovation for strategic decision making in construction businesses. Construciton Management and Economics, 25, 963-78.

R14 Lim, J N, Ofori, G, Yean, Y, Ling, F and Goh, B H (2007a) Role of national institutions in promoting innovation by contractors in Singapore. Construction Management and Economics, 25(10), 1021-39. 
R15 Lim, J N, Schultmann, F and Ofori, G (2010) Tailoring Competitive Advantages Derived from Innovation to the Needs of Construction Firms. Journal of Construction Engineering and Management, 136(5), 568-80.

R16 Mahapatra, K and Gustavsson, L (2008) Multi-storey timber buildings: breaking industry path dependency. 36, 6(638-648).

R17 Manley, K (2008) Against the odds: Small firms in Australia successfully introducing new technology on construction projects. Research Policy, 37(10), 1751-64.

R18 Manley, K (2008b) Implementation of innovation by manufacturers subcontracting to construction projects. Engineering, Construction and Architectural Management, 15(3), 230-45.

R19 Manley, K and McFallan, S (2006) Exploring the drivers of firm-level innovation in the construction industry. Construction Management and Economics, 24(9), 91120.

R20 McCabe, A, Parker, R and Brown, K (2011) Social outcomes in the construction industry: the case of the Western Australian 'Percent for Art' policy. Construction Management and Economics, 29(9), 929-41.

R21 Orstavik, Finn Innovation as re-institutionalization: a case study of technological change in housebuilding in Norway. Construction Management \& Economics. Sep 2014, Vol. 32 Issue 9, p 857-873..

R22 Pellicer, E, Yepes, V and Rojas, R J (2010) Innovation and Competitiveness in Construction Companies. Journal of Management Research, 10(2), 103-15.

R23 Rutten, M E J, Dorée, A G and Halman, J I M (2014) Together on the path to construction innovation: yet another example of escalation of commitment? Construction Management and Economics, 32(7/8), 695-704.

R24 Tombesi, P (2006) Good thinking and poor value: on the socialization of knowledge in construction. Building Research \& Information, 34(3), 272-86.

R25 Unsal, H I and Taylor, JE (2011) Absorptive Capacity of Project Networks. Journal of Construction Engineering and Management, 137(11), 994-1002.

R26 Wennberg, K, Wiklund, J and Wright, M (2011) The effectiveness of university knowledge spillovers: Performance differences between university spinoffs and corporate spinoffs. Research Policy, 40(8), 1128-43.

Citations to Harty (2008)

H1 Berente, N, BaxterRyan and Lyytinen, K (2010) Dynamics of inter-organizational knowledge creation and information technology use across object worlds: the case of an innovative construction project. Construction Management and Economics, 28(6), 569-88.

H2 Clegg, S and Kreiner, K (2014) Fixing concrete: inquiries, responsibility, power and innovation. Construction Management and Economics, 32(3), 262-78.

H3 Eriksson, P E and Westerberg, M (2011) Effects of cooperative procurement procedures on construction project performance: A conceptual framework. International Journal of Project Management, 29(2), 197-208.

H4 Eriksson, P E (2013) Exploration and exploitation in project-based organizations: Development and diffusion of knowledge at different organizational levels in 
construction companies. International Journal of Project Management, 31(3), 333-41.

H5 Georg, S and Tryggestad, K (2009) On the emergence of roles in construction: the qualculative role of project management. Construction Management and Economics, 27(10), 969-81.

H6 Guo, F, Chang-Richards, Y, Wilkinson, S and Li, T-C (2014) Effects of project governance structures on the management of risks in major infrastructure projects: A comparative analysis. International Journal of Project Management, 32(5), 815-26.

H7 Harty, C and Whyte, J (2010) Emerging Hybrid Practices in Construction Design Work: Role of Mixed Media. Construction Engineering and Management, 136(4), 46876.

H8 Kjellberg, H (2010) Struggling to perform a warehouse: buildings as symbols and tools. Construction Management and Economics, 28(6), 675-94.

H9 Lingard, H C, Cooke, T and Blismas (2012) Designing for construction workers' occupational health and safety: a case study of socio-material complexity. Construction Management and Economics, 30(5), 367-82.

H10 Lingard, H C, Pirzadeh, P, Blismas, N, Wakefield, R and Kleiner, B (2014) Exploring the link between early constructor involvement in project decision-making and the efficacy of health and safety risk control. Construciton Management and Economics, 32(9), 918-31.

H11 Liu, L, Wang, X and Sheng, Z (2012) Achieving ambidexterity in large, complex engineering projects: a case study of the Sutong Bridge project. Construciton Management and Economics, 30(5), 399-409.

H12 Lloyd-Walker, B M, Mills, A J and Walker, D H T (2014) Enabling construction innovation: the role of a no-blame culture as a collaboration behavioural driver in project alliances. Construction Management and Economics, 32(3), 229-45.

H13 Neff, G, Fiore-Silfvast, B and Dossick, C S (2010) A case study of the failure of digital communication to cross knowledge boundaries in virtual construction. Information, Communication and Society, 13(4), 556-73.

H14 Nordin, F, Öberg, C, Kollberg, B and Nord, T (2010) Building a new supply chain position: an exploratory study of companies in the timber housing industry. Construciton Management and Economics, 28(10), 1071-83.

H15 Pellicer, E, Yepes, V, Correa, C L and Alarcón, L F (2014) Model for Systematic Innovation in Construction Companies. Journal of Construction Engineering and Management, 14(4), B4014001-1-8.

H16 Wagner, H T, Morton, S C, Dainty, A R J and Burns, N D (2011) Path dependent constraints on innovation programmes in production and operations management. International Journal of Production Research, 49(11), 3069-85.

H17 Sage, D, Dainty, A and Brookes, N (2010) A 'Strategy-as-Practice' exploration of lean construction strategizing. Building Research \& Information, 40(2), 221-30..

H18 Sage, D, Dainty, A, Tryggestad, K, Justesen, L and Mouritsen, J (2014) Building with wildlife: project geographies and cosmopolitics in infrastructure construction. Construction Management and Economics, 32(7/8), 773-86. 
H19 Schweber, L and Harty, C (2010) Actors and objects: a socio-technial networks approach to technology uptake in the construction sector. Construction Management and Economics, 28(6), 657-74.

H20 Styhre, A (2010) The culture of complaint in construction: affirmative reflections on its role and function. Construction Management and Economics, 28(7), 797-803.

H21 Styhre, A and Gluch, P (2010) Managing knowledge in platforms: boundary objects and stocks and flows of knowledge. Construction Management and Economics, 28(6), 589-99.

H22 Tryggestad, K, Georg, S and Hernes, T (2010) Constructing buildings and design ambitions. Construction Management and Economics, 28(6), 695-705.

H23 Tryggestad, K and Georg, S (2011) How objects shape logics in construction. Culture and Organization, 17(3), 181-97.

H24 Unsal, H I and Taylor, J E (2011) Absorptive Capacity of Project Networks. Journal of Construction Engineering and Management, 137(11), 994-1002.

H25 Whyte, J and Sexton, M (2011) Motivations for innovation in the built environment: new directions for research. Building Research \& Information, 39(5), 473-82. 


\section{Appendix 2: Classification of detailed references to Reichstein et al and Harty's papers}

\section{Detailed referneces to Reichstein, et al (2005)}

\begin{tabular}{|c|c|c|c|}
\hline Reference & $\begin{array}{l}\text { Citation } \\
\text { Type }\end{array}$ & Main Point & Citation \\
\hline R6 & $\begin{array}{l}\text { Academic } \\
\text { common } \\
\text { sense }\end{array}$ & $\begin{array}{l}\text { Low innovation in } \\
\text { construction }\end{array}$ & $\begin{array}{l}\text { Footnote: This is supported by a Danish survey covering the } \\
\text { period } 1998-2000 \text {. The survey found that, while } 58 \% \text { of firms in } \\
\text { the manufacturing industry and } 44 \% \text { of firms in trade and services } \\
\text { had introduced new products or services during the period } \\
\text { covered by the survey, the corresponding figure in the } \\
\text { construction industry was only } 22 \% \text {. Source: Aalborg University, } \\
2001 \text {, Survey on Organisation, Employee Qualifications and New } \\
\text { Product Development. Reichstein et al. (2005) find similar results } \\
\text { for the UK. }\end{array}$ \\
\hline R8 & $\begin{array}{l}\text { Academic } \\
\text { common } \\
\text { sense }\end{array}$ & $\begin{array}{l}\text { Perceived low level } \\
\text { of innovation }\end{array}$ & $\begin{array}{l}\text { Traditionally, the construction sector has been seen as a low tech } \\
\text { industry, with little innovation compared to other industries } \\
\text { (Reichstein et al., 2005; Harty, 2008). }\end{array}$ \\
\hline R8 & $\begin{array}{l}\text { Academic } \\
\text { common } \\
\text { sense }\end{array}$ & $\begin{array}{l}\text { Innovation in } \\
\text { construction }\end{array}$ & $\begin{array}{l}\text { In recent years, however, innovation in construction has received } \\
\text { increasing interest in an explicit manner, both among } \\
\text { practitioners and academics (Reichstein et al., 2005). }\end{array}$ \\
\hline R9 & $\begin{array}{l}\text { Academic } \\
\text { common } \\
\text { sense }\end{array}$ & $\begin{array}{l}\text { Perceived low level } \\
\text { of innovation }\end{array}$ & $\begin{array}{l}\text { Again, this is somewhat at odds with the common perception of } \\
\text { these firms as having low absorptive capacity (REICHSTEIN et al., } \\
\text { 2005). }\end{array}$ \\
\hline R12 & $\begin{array}{l}\text { Academic } \\
\text { common } \\
\text { sense }\end{array}$ & $\begin{array}{l}\text { Classification of } \\
\text { construction as low } \\
\text { tech }\end{array}$ & $\begin{array}{l}\text { Construction, at least in the U.K., is generally classified as a "low- } \\
\text { tech" sector Pavitt 1984; Tidd et al. 1997; Reichstein et al. } 2005 \text {. }\end{array}$ \\
\hline R15 & $\begin{array}{l}\text { Academic } \\
\text { common } \\
\text { sense }\end{array}$ & $\begin{array}{l}\text { Classification of } \\
\text { construction as low } \\
\text { tech }\end{array}$ & $\begin{array}{l}\text { This term "industrialization," has led various writers, since the } \\
1980 \text { s such as Hounshell 1984, Egan 1998, and Reichstein et al. } \\
2005 \text {, to categorize construction as a traditional or low } \\
\text { technology sector. }\end{array}$ \\
\hline R16 & $\begin{array}{l}\text { Academic } \\
\text { common } \\
\text { sense }\end{array}$ & $\begin{array}{l}\text { Classification of } \\
\text { construction as low } \\
\text { tech }\end{array}$ & $\begin{array}{l}\text { Construction is regarded as a mature, slow-to-change sector } \\
\text { (Gann, 1994) where technological change can take several } \\
\text { decades (Grübler et al., 1999). This is due to the characteristics of } \\
\text { the industry (Nam and Tatum, 1988; Goverse et al., 2001; } \\
\text { Reichstein et al., 2005) }\end{array}$ \\
\hline R16 & $\begin{array}{l}\text { Academic } \\
\text { common } \\
\text { sense }\end{array}$ & Low growth & $\begin{array}{l}\text { The growth and productivity of the construction industry in } \\
\text { Europe has stagnated since } 1991 \text { (European Commission, 2000) } \\
\text { and lagged far behind the manufacturing sector (Gann, 1994; } \\
\text { Organization for Economic Cooperation and Development (OECD), } \\
\text { 2000; Koskela and Vrijhoef, 2001; Reichstein et al., 2005). This is } \\
\text { due to the characteristics of the industry (Nam and Tatum, 1988; }\end{array}$ \\
\hline
\end{tabular}




\begin{tabular}{|c|c|c|c|}
\hline & & & Goverse et al., 2001; Reichstein et al., 2005) \\
\hline R19 & $\begin{array}{l}\text { Academic } \\
\text { common } \\
\text { sense }\end{array}$ & $\begin{array}{l}\text { Perceived low level } \\
\text { of innovation }\end{array}$ & $\begin{array}{l}\text { The ability to successfully implement innovations adopted from } \\
\text { external sources is particularly important to contractors and } \\
\text { consultants in the construction industry, who have limited scope } \\
\text { to undertake R\&D and develop their own innovations due to the } \\
\text { constraints of project-based production and the pervasively low } \\
\text { profitability rates experienced by the majority of these industry } \\
\text { participants in Australia, as elsewhere (Reichstein et al., 2005, p. } \\
631 \text { ). }\end{array}$ \\
\hline R17 & $\begin{array}{l}\text { Academic } \\
\text { common } \\
\text { sense }\end{array}$ & $\begin{array}{l}\text { Low innovation in } \\
\text { construction }\end{array}$ & $\begin{array}{l}\text { In recent academic comparisons of innovation activity across } \\
\text { different sectors of the economy, construction underperforms } \\
\text { significantly compared to manufacturing (Reichstein et al., 2005). }\end{array}$ \\
\hline R20 & $\begin{array}{l}\text { Academic } \\
\text { common } \\
\text { sense }\end{array}$ & $\begin{array}{l}\text { Construction sector } \\
\text { as fragmented and } \\
\text { specialized }\end{array}$ & $\begin{array}{l}\text { In particular, the construction industry is generally characterized } \\
\text { by a separation between design and production divisions and an } \\
\text { extreme specialization of skills that limit feedback and interaction } \\
\text { (Rosenfeld, 1994; Pries and Janszen, 1995; Kumaraswamy and } \\
\text { Dulaimi, 2001; Dulaimi et al., 2005; Reichstein et al., 2005) }\end{array}$ \\
\hline $\mathrm{R} 21$ & $\begin{array}{l}\text { Academic } \\
\text { common } \\
\text { sense }\end{array}$ & $\begin{array}{l}\text { Low innovation in } \\
\text { construction }\end{array}$ & $\begin{array}{l}\text { Available statistics have been analysed by Reichstein et al. (2005), } \\
\text { who even when defining the construction industry more broadly } \\
\text { to include knowledge-intensive services, conclude that this sector } \\
\text { is 'last among equals' in innovation performance }\end{array}$ \\
\hline R23 & $\begin{array}{l}\text { Academic } \\
\text { common } \\
\text { sense }\end{array}$ & $\begin{array}{l}\text { Perceived low level } \\
\text { of innovation }\end{array}$ & $\begin{array}{l}\text { When it comes to innovation, it has been suggested that the } \\
\text { construction industry is characterized by a low rate of innovation, } \\
\text { also described as 'zephyrs of creative destruction' (Winch, 1998). } \\
\text { Although there is disagreement about whether this perception is } \\
\text { accurate (Winch, 2003; Reichstein et al., 2005; Hooker and Achur, } \\
\text { 2014), }\end{array}$ \\
\hline R25 & $\begin{array}{l}\text { Academic } \\
\text { common } \\
\text { sense }\end{array}$ & $\begin{array}{l}\text { Low innovation in } \\
\text { construction }\end{array}$ & $\begin{array}{l}\text { The construction industry has been described as not being } \\
\text { innovative (Harty 2008; Reichstein et al. 2005) }\end{array}$ \\
\hline R26 & $\begin{array}{l}\text { Academic } \\
\text { common } \\
\text { sense }\end{array}$ & $\begin{array}{l}\text { Construction as } \\
\text { knowledge } \\
\text { intensive }\end{array}$ & $\begin{array}{l}\text { Finally, we note that in-depth industry analyses have shown that } \\
\text { the construction/engineering (Reichstein et al., 2005) and finance } \\
\text { and advertising (Wennberg, 2009) industries have been shown to } \\
\text { be knowledge intensive. }\end{array}$ \\
\hline R1 & Approach & $\begin{array}{l}\text { Classification } \\
\text { problem }\end{array}$ & $\begin{array}{l}\text { When Reichstein et al. (2005) analysed the construction sector } \\
\text { responses from the } 2001 \text { UK innovation survey, they compared } \\
\text { construction with low- as well as high-technology manufacturing, } \\
\text { finding that construction, in particular the smaller firms, } \\
\text { resembled traditional service industries. They asserted that } \\
\text { service industries provide a body of knowledge about innovation } \\
\text { that might be 'extremely useful' for improving innovative } \\
\text { performance in construction. }\end{array}$ \\
\hline
\end{tabular}




\begin{tabular}{|c|c|c|c|}
\hline R5 & Approach & $\begin{array}{l}\text { Research design: } \\
\text { six liabilities to } \\
\text { innovation }\end{array}$ & $\begin{array}{l}\text { While there is a consensus that construction is a low-performing } \\
\text { sector in terms of innovation (Pries and Janszen, 1995; Slaughter, } \\
\text { 1998; Sexton and Barrett, 2003), the reasons for this remain } \\
\text { unclear; Reichstein et al. (2005) identify six factors, unique to the } \\
\text { industry, affecting the UK construction industry's ability to } \\
\text { innovate: }\end{array}$ \\
\hline R9 & Approach & $\begin{array}{l}\text { Classification } \\
\text { problem }\end{array}$ & $\begin{array}{l}\text { footnote: Construction is a service industry, but its innovation } \\
\text { processes and activities are often quite different from other } \\
\text { industries (REICHSTEIN et al., 2005), and it is therefore often } \\
\text { treated separately in industrial classifications }\end{array}$ \\
\hline R11 & Approach & $\begin{array}{l}\text { Classification } \\
\text { problem }\end{array}$ & $\begin{array}{l}\text { However Reichstein et al. (2005) have pointed out the difficulties } \\
\text { in using surveys based on the Oslo Manual (in that case the } \\
\text { Innovation Survey by the Manual (in that case the Innovation } \\
\text { Survey by the UK's DTI) for understanding construction innovation } \\
\text { heritage. }\end{array}$ \\
\hline R14 & Approach & $\begin{array}{l}\text { Classification } \\
\text { problem }\end{array}$ & $\begin{array}{l}\text { Specifically for the construction sector, Reichstein et al. (2005) } \\
\text { discuss the various methods of classifying construction } \\
\text { innovation. }\end{array}$ \\
\hline R13 & Approach & $\begin{array}{l}\text { Research design, } \\
\text { not followed }\end{array}$ & $\begin{array}{l}\text { To overcome such limitations in investigating innovation in the } \\
\text { construction industry, Reichstein et al.'s (2005) study of the } \\
\text { innovative behaviour of construction firms grouped architecture, } \\
\text { engineering consultancy and associated services into the broad } \\
\text { definition of the 'construction industry'. This study has refrained } \\
\text { from doing likewise. }\end{array}$ \\
\hline R15 & Approach & $\begin{array}{l}\text { Research design: } \\
\text { six liabilities to } \\
\text { innovation }\end{array}$ & $\begin{array}{l}\text { Reichstein et al. } 2005 \text { following Nam and Tatum } 1988 \text { identified } \\
\text { six factors that shape the nature of innovation in construction } \\
\text { Table } 2\end{array}$ \\
\hline R16 & Approach & $\begin{array}{l}\text { Research design: } \\
\text { six liabilities to } \\
\text { innovation }\end{array}$ & $\begin{array}{l}\text { Reichstein et al. (2005) expanded the list to six characteristics, } \\
\text { which they term as liabilities. }\end{array}$ \\
\hline R18 & Approach & Statistical analysis & $\begin{array}{l}\text { The qualitative methods adopted here provide rich, detailed } \\
\text { findings that complement the broad view provided by } \\
\text { quantitative methods, such as statistical manipulation of } \\
\text { innovation survey data (e.g. Reichstein et al., 2005). }\end{array}$ \\
\hline R24 & Approach & $\begin{array}{l}\text { Market belonging } \\
\text { variable }\end{array}$ & $\begin{array}{l}\text { The market-belonging variable, however, is often invoked (Winch, } \\
\text { 1998; Gann, 2000; Reichstein et al., 2005) but seldom employed } \\
\text { in the exegesis of technical change. }\end{array}$ \\
\hline R15 & $\begin{array}{l}\text { Authors } \\
\text { Contribution }\end{array}$ & Locked system & $\begin{array}{l}\text { Both Reichstein et al. and Nam and Tatum cited these } \\
\text { characteristics as creating a "locked system" in which innovation, } \\
\text { or changing the status quo, becomes difficult. }\end{array}$ \\
\hline
\end{tabular}




\begin{tabular}{|c|c|c|c|}
\hline R2 & $\begin{array}{l}\text { Authors } \\
\text { Contribution }\end{array}$ & $\begin{array}{l}\text { Liabilities of } \\
\text { immobility and dd }\end{array}$ & $\begin{array}{l}\text { Reichstein et al. (2005) attribute low innovation in the industry } \\
\text { mainly to 'liabilities of immobility and unexpected demand'. }\end{array}$ \\
\hline R17 & $\begin{array}{l}\text { Authors } \\
\text { Contribution }\end{array}$ & $\begin{array}{l}\text { Small firms more } \\
\text { likely to find } \\
\text { regulations an } \\
\text { obstacle }\end{array}$ & $\begin{array}{l}\text { This finding is supported by data from the UK Innovation Survey } \\
\text { conducted in } 2001 \text { which shows that small firms are more likely to } \\
\text { find regulations an obstacle to their innovation activity than large } \\
\text { firms (Reichstein et al., 2005). }\end{array}$ \\
\hline R20 & $\begin{array}{l}\text { Authors } \\
\text { Contribution }\end{array}$ & $\begin{array}{l}\text { SS chain as source } \\
\text { of innovation }\end{array}$ & $\begin{array}{l}\text { Technological advances introduce new tools, design techniques or } \\
\text { components, often introduced by suppliers (Slaughter, 1993; } \\
\text { Blayse and Manley, 2004; Reichstein et al., 2005). }\end{array}$ \\
\hline R20 & $\begin{array}{l}\text { Authors } \\
\text { Contribution }\end{array}$ & $\begin{array}{l}\text { SS chain as source } \\
\text { of innovation }\end{array}$ & $\begin{array}{l}\text { Essentially these alternative instigators implement new products } \\
\text { or processes of procurement which result in change to the design, } \\
\text { function or aesthetics of the built asset (Ling, 2003; Walker et al., } \\
2003 \text {; Blayse and Manley, 2004; Reichstein et al., 2005). }\end{array}$ \\
\hline R22 & $\begin{array}{l}\text { Authors } \\
\text { Contribution }\end{array}$ & $\begin{array}{l}\text { SS chain as source } \\
\text { of innovation }\end{array}$ & $\begin{array}{l}\text { Several studies (Van de Ven, 1986; Tatum, 1989; Thomas and } \\
\text { Bone, 2000; Reichstein, Salter and Gann, 2005) highlight the fact } \\
\text { that the nature of the supply chain largely determines the quality } \\
\text { and rate of innovation in that sector. }\end{array}$ \\
\hline R1 & $\begin{array}{l}\text { General } \\
\text { Contribution }\end{array}$ & $\begin{array}{l}\text { Importance of } \\
\text { inter-organizational } \\
\text { ties for innovation }\end{array}$ & $\begin{array}{l}\text { There are many studies of how innovation is related to } \\
\text { information flows between contractors and other firms in the } \\
\text { construction sector, as well as to and from external research } \\
\text { institutions (Anderson and Schaan, 2001; Cleff and Rudolph-Cleff, } \\
\text { 2001; Miozzo and Dewick, 2004; Manley, 2005; Reichstein et al., } \\
\text { 2005; Manley and McFallan, 2006; Barrett et al., 2008). }\end{array}$ \\
\hline R3 & $\begin{array}{l}\text { General } \\
\text { Contribution }\end{array}$ & $\begin{array}{l}\text { Finance as obstacle } \\
\text { to innov }\end{array}$ & $\begin{array}{l}\text { Many studies have also reported contractors' very limited access } \\
\text { to finance in general and bank loans in particular, and considered } \\
\text { this inaccessibility a major barrier to innovation (Pries and } \\
\text { Janszen, 1995; Raftery et al ., 1998; Fox et al., 1999; Ngowi et al., } \\
\text { 2005, 2006; Hawk, 2006; Fox and Skitmore, 2007) or a major } \\
\text { reason for business failure (Enshassi et al., 2006). Consequently, } \\
\text { contractors have to look elsewhere for innovation (Kale and } \\
\text { Arditi, 2002; Reichstein et al., 2005). }\end{array}$ \\
\hline R4 & $\begin{array}{l}\text { General } \\
\text { Contribution }\end{array}$ & $\begin{array}{l}\text { Finance as obstacle } \\
\text { to innov }\end{array}$ & $\begin{array}{l}\text { After all, contractors in other countries have also found limited } \\
\text { access to finance their major problem (Fox and Skitmore, 2007; } \\
\text { Enshassi et al., 2006; Reichstein et al., 2005; Fox et al., 1999). }\end{array}$ \\
\hline R7 & $\begin{array}{l}\text { General } \\
\text { Contribution }\end{array}$ & $\begin{array}{l}\text { Sector low R\&D } \\
\text { investment }\end{array}$ & $\begin{array}{l}\text { Other studies show that R\&D expenditures are extremely low in } \\
\text { construction companies (Miozzo and Dewick, 2004; Reichstein et } \\
\text { al., 2005). }\end{array}$ \\
\hline R10 & $\begin{array}{l}\text { General } \\
\text { Contribution }\end{array}$ & $\begin{array}{l}\text { Business } \\
\text { environment and } \\
\text { innovation } \\
\text { outcomes }\end{array}$ & $\begin{array}{l}\text { Another common trait of SMEs is their agility and flexibility } \\
\text { (Dainty et al., 2001), yet this strategic advantage also creates a } \\
\text { significant challenge, in that the firm must constantly scan its } \\
\text { external environment (Reichstein et al., 2005), }\end{array}$ \\
\hline
\end{tabular}




\begin{tabular}{|c|c|c|c|}
\hline R15 & $\begin{array}{l}\text { General } \\
\text { Contribution }\end{array}$ & $\begin{array}{l}\text { Nature of sector } \\
\text { client involvement }\end{array}$ & $\begin{array}{l}\text { Reichstein et al. } 2005 \text { observed that in construction, clients often } \\
\text { play a significant role in shaping the design and production } \\
\text { process. }\end{array}$ \\
\hline R15 & $\begin{array}{l}\text { General } \\
\text { Contribution }\end{array}$ & $\begin{array}{l}\text { Nature of sector } \\
\text { client involvement }\end{array}$ & $\begin{array}{l}\text { Reichstein et al. } 2005 \text { observed that for the construction sector, } \\
\text { demand usually depends upon fixed capital investment decisions, } \\
\text { where clients and several stakeholders often play a significant } \\
\text { role in shaping the design and the production processes. }\end{array}$ \\
\hline R19 & $\begin{array}{l}\text { General } \\
\text { Contribution }\end{array}$ & $\begin{array}{l}\text { Business } \\
\text { environment and } \\
\text { innovation } \\
\text { outcomes }\end{array}$ & $\begin{array}{l}\text { This model focuses on the key roles played by the business } \\
\text { environment and business strategies in driving or impeding } \\
\text { innovation outcomes (Porter, 1990; Tzokas and Saren, 1997; } \\
\text { Manley, 2003a; Seaden et al., 2003; Ritter and Gemunden, 2004; } \\
\text { Reichstein et al., 2005). }\end{array}$ \\
\hline R20 & $\begin{array}{l}\text { General } \\
\text { Contribution }\end{array}$ & $\begin{array}{l}\text { Sector low R\&D } \\
\text { investment }\end{array}$ & $\begin{array}{l}\text { The construction industry is further characterized by high levels of } \\
\text { financial accountability (Macmillan 2006), capital investment from } \\
\text { clients, low research and development expenditure (Reichstein et } \\
\text { al., 2005) }\end{array}$ \\
\hline R20 & $\begin{array}{l}\text { General } \\
\text { Contribution }\end{array}$ & $\begin{array}{l}\text { Democratic } \\
\text { decision making }\end{array}$ & $\begin{array}{l}\text { The significance of democratic decision-making is that it forms } \\
\text { part of the bridge between the design and production divisions by } \\
\text { facilitating feedback and interaction between members in } \\
\text { decision-making (Rosenfeld, 1994; Pries and Janszen, 1995; } \\
\text { Kumaraswamy and Dulaimi, 2001; Dulaimi et al., 2005; Reichstein } \\
\text { et al., 2005). }\end{array}$ \\
\hline
\end{tabular}


Detailed references to Harty (2008)

\begin{tabular}{|c|c|c|c|}
\hline Reference & $\begin{array}{l}\text { Citation } \\
\text { Type }\end{array}$ & Main point & Citation \\
\hline $\mathrm{H} 1$ & $\begin{array}{l}\text { Academic } \\
\text { common } \\
\text { sense }\end{array}$ & $\begin{array}{l}\text { Governance of project } \\
\text { forms }\end{array}$ & $\begin{array}{l}\text { Thus governance of project forms is an area that could benefit from more } \\
\text { attention (Scarbrough et al ., 2004; Harty, 2008). }\end{array}$ \\
\hline H3 & $\begin{array}{l}\text { Academic } \\
\text { common } \\
\text { sense }\end{array}$ & $\begin{array}{l}\text { Construction as low } \\
\text { tech }\end{array}$ & $\begin{array}{l}\text { Traditionally, the construction sector has been seen as a low tech industry, with } \\
\text { little innovation compared to other industries (Reichstein et al., 2005; Harty, } \\
\text { 2008). }\end{array}$ \\
\hline H11 & $\begin{array}{l}\text { Academic } \\
\text { common } \\
\text { sense }\end{array}$ & $\begin{array}{l}\text { Project basis as } \\
\text { obstacle to innovation }\end{array}$ & $\begin{array}{l}\text { Many scholars believe that the temporary and decentralized nature of projects } \\
\text { and the loose couplings among construction organizations lead to a short-term } \\
\text { focus on productivity and efficiency, and represent major obstacles to innovation } \\
\text { (Dubois and Gadde, 2002; Harty, 2008).....Such a view is consistent with the } \\
\text { observation that the construction industry is not innovative (Wide'n and } \\
\text { Hansson, 2007) partially as a result of its project-based context (Dubois and } \\
\text { Gadde, 2002; Harty, 2008). }\end{array}$ \\
\hline $\mathrm{H} 12$ & $\begin{array}{l}\text { Academic } \\
\text { common } \\
\text { sense }\end{array}$ & $\begin{array}{l}\text { Radical innovation } \\
\text { (def) }\end{array}$ & $\begin{array}{l}\text { Radical innovation 'signifies a break with existing knowledge and activity' (Harty, } \\
2008, \text { p. 1031). }\end{array}$ \\
\hline $\mathrm{H} 14$ & $\begin{array}{l}\text { Academic } \\
\text { common } \\
\text { sense }\end{array}$ & $\begin{array}{l}\text { Project basis as } \\
\text { obstacle to innovation }\end{array}$ & $\begin{array}{l}\text { Harty }(2005,2008) \text { has described the problems in gaining acceptance of } \\
\text { innovations within the industry, referring specifically to innovations that result } \\
\text { from the interactive collaboration of actors on a construction site. }\end{array}$ \\
\hline $\mathrm{H} 20$ & $\begin{array}{l}\text { Academic } \\
\text { common } \\
\text { sense }\end{array}$ & $\begin{array}{l}\text { Example of other } \\
\text { industries }\end{array}$ & $\begin{array}{l}\text { Still, there are numerous commentators claiming that there is a need for } \\
\text { adopting and implementing new management tools and techniques developed in } \\
\text { for instance the manufacturing industry (see e.g. Harty, 2008). }\end{array}$ \\
\hline $\mathrm{H} 21$ & $\begin{array}{l}\text { Academic } \\
\text { common } \\
\text { sense }\end{array}$ & $\begin{array}{l}\text { Example of other } \\
\text { industries }\end{array}$ & $\begin{array}{l}\text { If, for instance, as Harty (2008, p. 1030) suggests, it is the case that the } \\
\text { automotive industry has been advanced by many commentators as a shining } \\
\text { example' for the construction industry, allegedly providing a role model for the } \\
\text { implementation and use of new organizational principles and managerial } \\
\text { practices and tools, then the distribution and implementation of management } \\
\text { ideas (see e.g. Sahlin-Andersson and Engwall, 2002) such as platforms deserve } \\
\text { more systematic research. }\end{array}$ \\
\hline $\mathrm{H} 24$ & $\begin{array}{l}\text { Academic } \\
\text { common } \\
\text { sense }\end{array}$ & $\begin{array}{l}\text { Low innovation in } \\
\text { construction }\end{array}$ & $\begin{array}{l}\text { The construction industry has been described as not being innovative (Harty } \\
\text { 2008; Reichstein et al. 2005) }\end{array}$ \\
\hline $\mathrm{H} 4$ & Approach & $\begin{array}{l}\text { specificity of project } \\
\text { basis }\end{array}$ & $\begin{array}{l}\text { However, the suggested improvement agenda fails to account for the specificities } \\
\text { of innovating within the project-based context (Dubois and Gadde, 2002; Harty, } \\
\text { 2008). }\end{array}$ \\
\hline
\end{tabular}




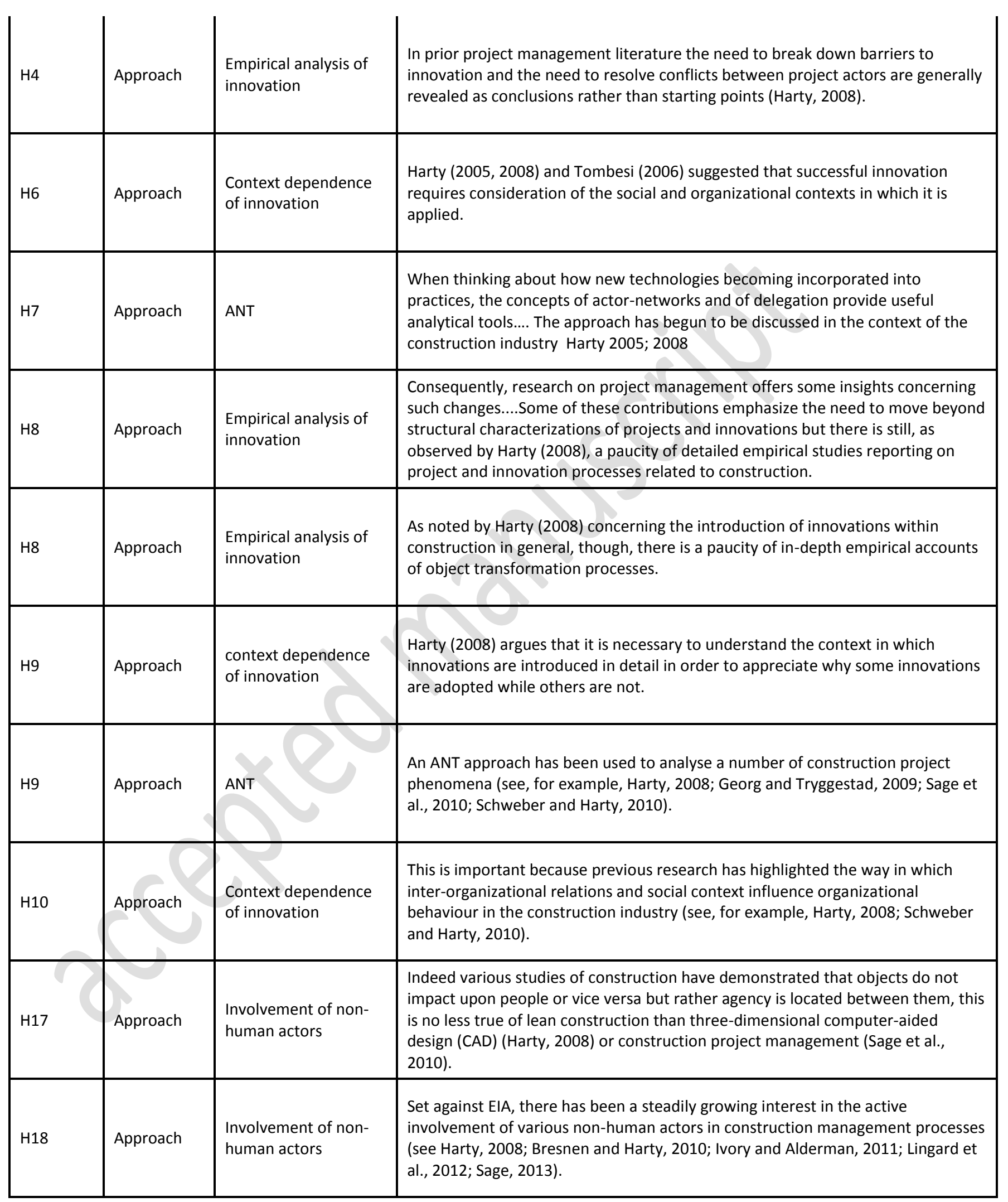




\begin{tabular}{|c|c|c|c|}
\hline $\mathrm{H} 22$ & Approach & ANT & $\begin{array}{l}\text { ANT is now being applied in organization and management studies (Kreiner, } \\
\text { 2002; Kreiner and Tryggestad, 2002; Czarniawska and Hernes, 2005; Enberg et al } \\
\text {., 2006; Kreiner, 2006; Hernes, 2008; Justesen and Mouritsen, 2009; Woolgar et } \\
\text { al ., 2009), but its use within construction management research is - with a few } \\
\text { notable exceptions (Harty, 2005; Ewenstein and Whyte, 2007; Whyte et al ., } \\
\text { 2007; Harty, 2008)-relatively limited }\end{array}$ \\
\hline $\mathrm{H} 23$ & Approach & Study of objects & $\begin{array}{l}\text { Several contributions within management and organization studies have } \\
\text { suggested that objects and models can be active in shaping business and strategy } \\
\text { (Corvellec 2002; Whittington 2004; Hansen and Mouritsen 2005; Tryggestad } \\
\text { 2005; Corvellec and Risberg 2007; Doganova and Eyquem-Renault 2009; } \\
\text { Skærbæk and Tryggestad 2010; Justesen and Mouritsen 2011), construction and } \\
\text { building design (Yaneva 2005; Harty 2008; Whyte et al. 2008; Bresnen and Harty } \\
\text { 2010; Tryggestad, Georg, and Hernes 2010; Våland 2010; Whyte and Lobo 2010). }\end{array}$ \\
\hline H25 & Approach & Study of objects & $\begin{array}{l}\text { Here technology development is constituted in essentially political terms, and the } \\
\text { focus is on: the delegation of interests on to technological artefacts and ... the } \\
\text { mobilization of actors and artefacts to constrain and limit the scope of } \\
\text { negotiations over new technology implementation. (Harty, 2008, p. 1029) }\end{array}$ \\
\hline $\mathrm{H} 17$ & Approach & $\begin{array}{l}\text { context dependence } \\
\text { of innovation }\end{array}$ & $\begin{array}{l}\text { However, as many other practice studies of construction have } \\
\text { shown, local adaptation to top-down initiatives can equally prove } \\
\text { advantageous, or necessary, in certain settings (Bresnen, 2009; } \\
\text { Harty, 2008; Sage et al., 2010). }\end{array}$ \\
\hline $\mathrm{H} 1$ & $\begin{array}{l}\text { Authors } \\
\text { Contribution }\end{array}$ & $\begin{array}{l}\text { Variation in effect of } \\
C A D\end{array}$ & $\begin{array}{l}\text { Further, we describe little about the motivation and processes behind embedding } \\
\text { the artefacts in project team practices. CAD artefacts are not adopted and } \\
\text { implemented across a construction project network without problems and only } \\
\text { with intended outcomes, and can have a variety of material effects (Harty, 2008). }\end{array}$ \\
\hline $\mathrm{H} 2$ & $\begin{array}{l}\text { Authors } \\
\text { Contribution }\end{array}$ & Bounded innovation & $\begin{array}{l}\text { Harty (2008, p. 1032) makes a distinction between bounded and unbounded } \\
\text { innovation. To name innovation as unbounded is to recognize that its 'effects or } \\
\text { repercussions extend beyond the control or sphere of influence of the } \\
\text { implementer'. Such a focus acknowledges the complexity of the context in } \\
\text { construction and the impact it has on the implementation of innovations. Harty } \\
\text { argues that more conventional distinctions between, for example, incremental or } \\
\text { radical innovation, and modular versus architectural innovation (Slaughter, 1998) } \\
\text { can be supplemented with the notion of relative boundedness. Harty's (2008) } \\
\text { contribution enables us to highlight an additional feature of innovation in } \\
\text { construction, namely its dynamic and ambiguous character. Innovating the 'small } \\
\text { things' involved in fixing concrete would appear to be a case of bounded } \\
\text { innovation. In our case it was, until a trivial mishap at a specific moment } \\
\text { generated effects and repercussions throughout the network of actors across the } \\
\text { sector, many of whom had not previously been involved in the project. } \\
\text { Instantaneously, it became a case of unbounded innovation. Suddenly, at a } \\
\text { certain point nobody seemed to be able to control its effects. }\end{array}$ \\
\hline H9 & $\begin{array}{l}\text { Authors } \\
\text { Contribution }\end{array}$ & $\begin{array}{l}\text { Unboundedness of } \\
\text { construction projects }\end{array}$ & $\begin{array}{l}\text { Harty (2008) suggests that construction projects are 'relatively unbounded' } \\
\text { contexts in which actor-networks are continually changing. He argues that an } \\
\text { ANT approach is ideally suited to the analysis of phenomena in relatively } \\
\text { unbounded contexts because it does not define, a priori, the boundaries of any } \\
\text { particular actor-network. }\end{array}$ \\
\hline $\mathrm{H} 13$ & $\begin{array}{l}\text { Authors } \\
\text { Contribution }\end{array}$ & $\begin{array}{l}\text { Relative boundedness } \\
\text { of communities of } \\
\text { practice }\end{array}$ & $\begin{array}{l}\text { The boundary object as a concept describes an epistemic tool that is robust } \\
\text { enough to uphold any necessary distinctions for knowledge specialization while } \\
\text { still providing cohesion for the communities around that expertise and remaining } \\
\text { flexible enough to link these distinct communities of practice to allow for limited, } \\
\text { or 'relatively bounded', collaboration (Harty 2005, 2008). }\end{array}$ \\
\hline
\end{tabular}




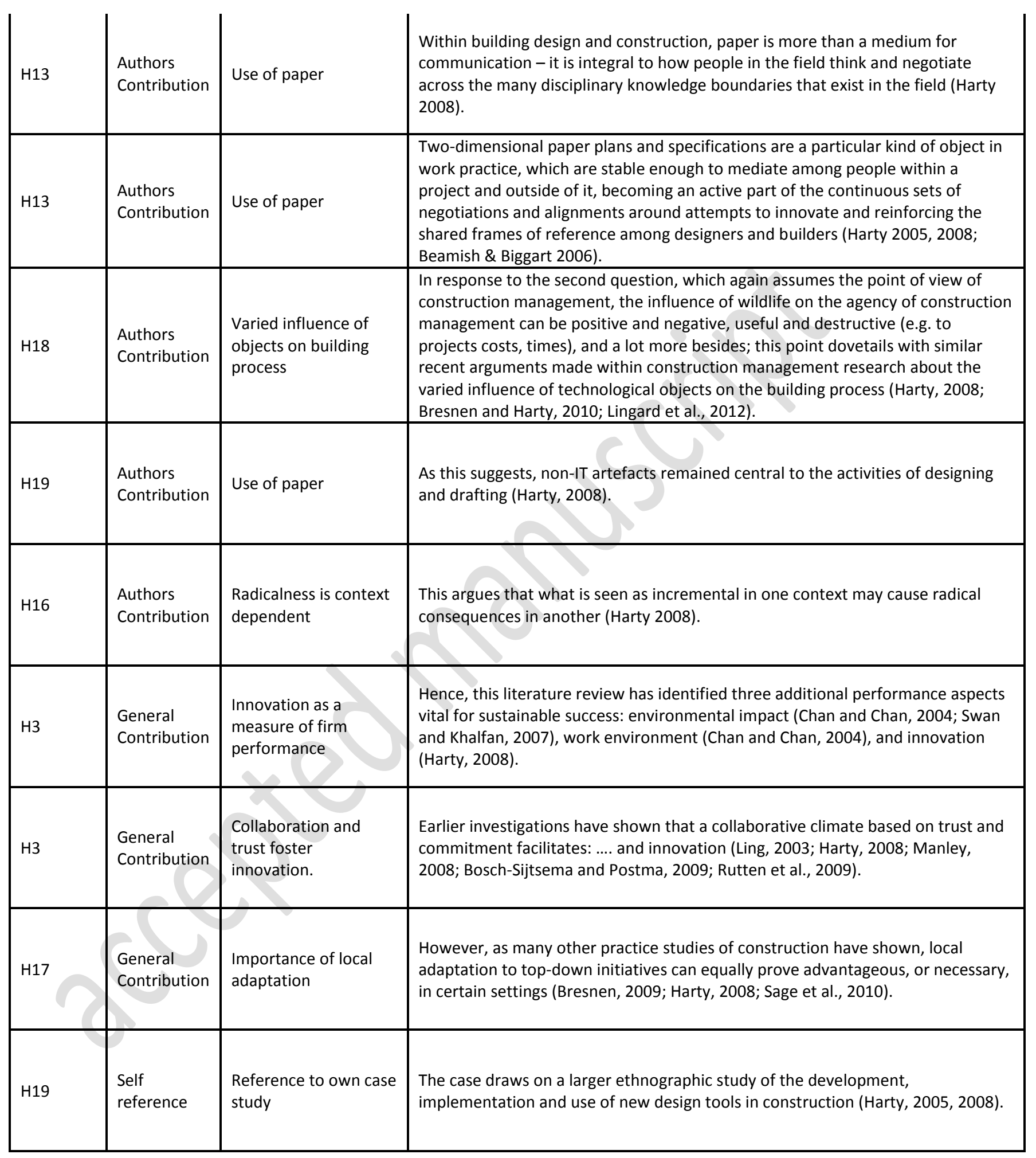




\section{References Cited}

Becher, T and Trowler, P (2001) Academic tribes and territories: intellectual enquiry and the culture of disciplines. Open University Press.

Davis, G F (2015) Celebrating Organization theory: The After-Party. Journal of Management Studies, 52(2), 309-19.

Davis, G F and Marquis, C (2005) Prospects for Organization Theory in the Early TwentyFirst Century: Instituitonal fields and mechanisms. Organization Science, 16(4), 332-43.

Guba, E G and Lincoln, Y S (1994) Competing paradigms in qualitative research. In: Denzin, N K and Lincoln, Y S (Eds.), Handbook of Qualitative Research. Thousand Oaks, CA: Sage.

Hammersley, M (1992) By what criteria should ethnographic research be judged. In: Hammersley, M (Ed.), Whats wrong with ethnography? London: Routledge.

Harty, C (2008) Implementing innovation in construction: contexts, relative boundedness and actor-network theory. Construction Management and Economics, 26, 1029-41.

Heilbron, J (1995) The rise of social theory. Polity Press.

Hollis, M (1994) The philosophy of social science. Cambridge: University of Cambridge Press.

Hume, D (2011 (1748)) An enquiry concerning human understanding A Millar. Boston, MA USA: Simon and Brown.

Keat, R and Urry, J (1982) Social Theory as Science. London: Routledge \& Kegan Paul.

Kuhn, T S (1996) The Structure of Scientific Revolutions. Chicago: University of Chicago.

Lange, M (2012) Comparative-Historical Methods. Thousand Oaks, CA: Sage Publications Ltd.

Lousnbury, M and Beckman, C M (2015) Celebrating Organization Theory. Journal of Management Studies, 52(2), 288-308.

Neumann, W L (2006) Social Research Methods, sixth edition. Boston, MA: Pearson International Edition.

Niiniluoto, I (2015) Scientific Progress. In: The Stanford Encyclopedia of Philosophy, Zalta, E N, Ed.), http://plato.stanford.edu/archives/sum2015/entries/scientificprogress/ (accessed 06/10/2015).

Popper, K (1962/2002) Conjectures and Refutations: The growth of scientific knowledge, 2nd edition. Routledge.

Reichstein, T, Salter, A J and Gann, D M (2005) Last among equals: a comparison of innovation in construction, services and manufacturing in the UK. Construction Management and Economics, 23, 631-44.

Schweber, L and Leiringer, R (2012) Beyond the technical: A snapshot of energy and buildings research. Research and Information, 40(4), 481-92.

Slaughter, E S (1998) Models of construction innovation. Journal of Construction Engineering and Management, 124(3), 226-31.

Weber, M (2011 (1903-1917)) Methodology of Social Sciences. Transaction Publishers. Winch, P (1958) The Idea of a Social Science and its Relation to Philosophy. New York: Routledge. 


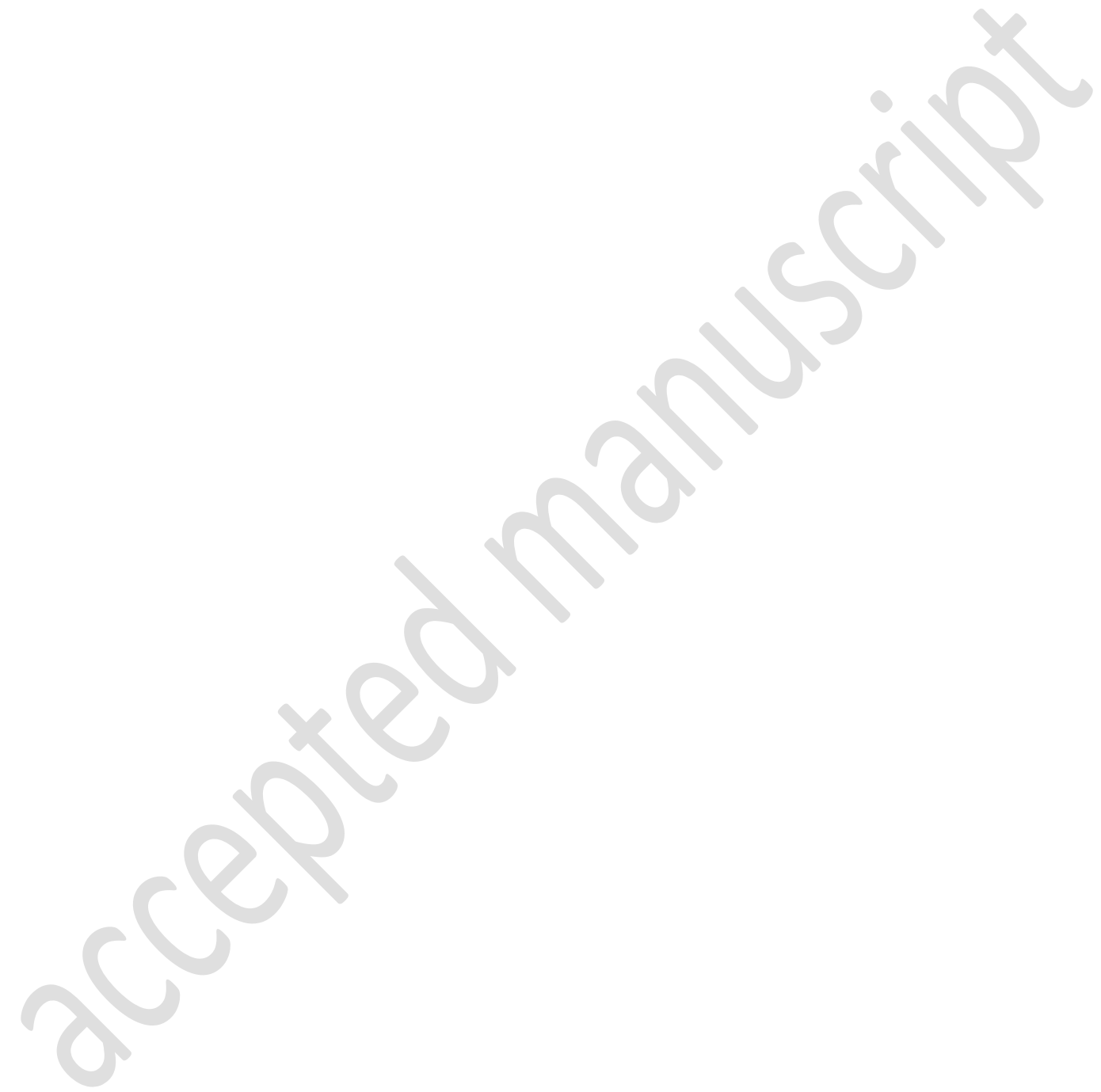

